\title{
The Benefits of French-English Bilingual Competence in Cameroon
}

\author{
Jean-Paul Kouega \\ University of Yaounde I, Yaounde, Cameroon \\ Email: jkouega@yahoo.co.uk
}

How to cite this paper: Kouega, J.-P. (2018) The Benefits of French-English Bilingual Competence in Cameroon. Open Access Library Journal, 5: e4409. https://doi.org/10.4236/oalib.1104409

Received: February 5, 2018

Accepted: March 3, 2018

Published: March 6, 2018

Copyright (๑) 2018 by author and Open Access Library Inc.

This work is licensed under the Creative Commons Attribution International License (CC BY 4.0).

http://creativecommons.org/licenses/by/4.0/

(c) (i) Open Access

\begin{abstract}
Cameroon is said to be an officially French-English bilingual country. This paper explores the possible benefits of French-English bilingual competence to the individual working citizen in the country. The data are the returns of a 16-item questionnaire devised to check the possible advantages that working Cameroonian French-English bilinguals have and that "officially monolingual" workers do not. The informants are some 408 competent French-English bilinguals working in both the public and private sectors in the city of Yaounde and a few other towns. The findings revealed that, compared to "officially monolingual" workers, "officially bilingual" workers have no advantage in entering the labour market, in salary increase, in being promoted within a job or receiving any distinction in the work place. The paper establishes that bilingualism has no labour market value in Cameroon and that this policy is a mere slogan, no one caring about its implementation. As a result, the bulk of the working force of the nation has remained officially monolingual over the years. With the advent of globalisation, there is a reversal of the situation. Francophone parents have understood that English language skills are likely to give their children a critical advantage in the global marketplace. To prepare for it, a greater number of urban francophone parents are registering their children in English-medium schools where these children acquire formal English in the classroom and oral/informal French around school premises and in the neighbourhood.
\end{abstract}

\section{Subject Areas}

Education

\section{Keywords}

Bilingualism, Bilingual Education, Language Policy, Policy Implementation, Globalisation 


\section{Introduction}

Since 1961, Cameroon has been implementing an official policy of French-English bilingualism and yet the vast majority of Francophone Cameroonians cannot operate in English. Some go so far as to claim that it is Cameroon which is bilingual and not Cameroonians. Government has been spending huge amounts of money (see Section 2 below) on its bilingualism policy, which is inscribed in the first constitution of the country as well as its subsequent revisions. However, past and recent research shows that very few bilinguals have been turned out over years. The purpose of this study is to explore the possible benefits of French-English bilingual competence to the individual worker within Cameroon and, incidentally, the underlying causes of the failure of this policy in Cameroon. The following four questions are set to guide the research exercise: Over the years, what measures has Government taken to promote its French-English bilingualism policy? Over the years, what assistance has Government been giving to active learners who exerted themselves to become French-English bilinguals? What range of benefits has Government envisaged for its workers who have toiled for many years and can in the end effectively operate in the two official languages of the country? And finally, can it be said that Government is serious about its official French-English bilingualism policy? This research is important in that it proposes a simple way of turning out a greater number of bilinguals while saving nearly all the budget provisions that had been allocated to this constitutional prescription. The work is divided into four sections entitled background to the study, research design, data analysis, and discussion. These are considered in turn.

\section{Background to the Study}

After the First World War, Cameroon, a German colony, was divided into two separate territories which were placed under the administration of the war victors i.e. France and Britain. In 1960, French Cameroon obtained its independence and called itself the Republic of Cameroon. As the territory included hundreds of tribes speaking different languages, the first legislators of independent Cameroon decided to adopt French, the ex-colonial master's language, as its official language. In 1961, part of British Cameroon, which had adopted English as its official language, obtained its independence by reuniting with the Republic of Cameroon. The country was renamed the Federal Republic of Cameroon with French and English as its joint official languages. In 1972, the country's name was changed to the United Republic of Cameroon, still with French and English being its official languages. Besides, it was pledged that bilingualism in these two languages will be promoted. Since then, several decisions-couched in the form of ordinances, decrees, circulars, service notes-have been taken by the State to ensure the spread of official bilingualism in the country. The most frequently cited and usually publicised decisions are listed below:

- linguistic centres were created to enable citizens to learn English and French, 
an activity which was originally restricted to the British Council, the American Cultural Center and the French Cultural Centre;

- translation services were offered in all State institutions and a school for the training of translators and interpreters (Advanced School of Translators and Interpreters-ASTI) was opened in Buea;

- bilingual secondary schools were created in various localities in the country;

- the bilingual degree programme was set up in the University of Yaounde and the Higher Teacher Training College (Ecole Normale Supérieure-ENS); today this programme is available in all State universities of the country;

- English became a subject in all French-medium secondary schools and French the same in all English-medium schools;

- the second official language became a subject in all public examinations, with francophone candidates writing an English language paper and Anglophone candidates writing a French language paper;

- the Official Gazette, which records the country's daily activities, was printed in the two languages and so was the official daily newspaper i.e. Cameroon Tribune published;

- the national radio and TV network (CRTV) alternated programmes in French and English at regular intervals.

- Since the year 1996, another battery of measures has been added to these older ones. These include the following:

- an order stipulating that every primary school teacher would henceforth teach every subject on the school syllabus including the second official language subject was issued (Order No 21/E/59 of May 15, 1996 organising the Grade One teacher certificate examination);

- a primary school syllabus outlining how each subject including the second official language subject would be taught was designed by the Ministry of Education (MINEDUC [1], Kouega [2]);

- an order introducing the second official language subject in both the written and oral parts of the First School Leaving Certificate (FSLC) examinations and its French equivalent, the Certificat d'Etudes Primaires (CEP) examinations (Order No 66/C/13 of February 16, 2001);

- a National Day of Bilingualism in public and private schools in Cameroon was instituted (Decision no 1141/B1/1464/MINEDUC/IGE/IGP/BIL of October 28, 2002); on this day, anglophone pupils are expected to communicate in French and francophone pupils in English;

- a circular letter instructing primary and nursery education state officials to see that bilingualism is effective in all nursery and primary schools (circular letter No 033/B1/1464/MINEDUC/IE/ IGPBIL of October 14, 2002);

- a circular letter instructing secondary education state officials to see that the National Bilingualism Day is observed in all schools and that, in addition, Language Clubs (LC), to be called "Club Français" for Anglophone pupils and "English Club" for Francophone pupils, be set up in all schools, that the National Anthem be sung in English and French on alternate days and that a 
prize be awarded to the best bilingual pupils in each class (Circular letter No B1/1464/MINEDUC/IGE/IGE/GP/BIL of December 2, 2002);

- a circular letter instructing teacher training college principals to provide adequate training so that student-teachers be sufficiently equipped to teach the second official language (Circular letter

No 009/B1/1464/MINEDUC/IGE/IGP/BIL of April 9, 2003); (see Abang [3] for an evaluation);

- a decision creating a bilingualism watchdog committee in the Ministry of Education, which is responsible for the observation, verification and supervision of the practice of bilingualism in central and external services of the Ministry of Education (Decision No 1230/B1/1464/MINEDUC/CAB of June $12,2003) \cdots$

It was envisaged that, after these decisions and measures are implemented fully, every Cameroonian citizen would be bilingual in French and English and every pupil who leaves secondary education would have learned enough French and English to be capable of following courses taught in either official language at tertiary education level. Government officials evaluated these measures and attempted to readjust them, hence the many decrees since 1975 (MINEDUC [4]). Similarly, various researchers evaluated these measures as they were implemented in the field. These include, among others: Constable [5], Tchoungui [6], Kouega ([2] [7] [8] [9] [10]), Biloa [11], Echu [12], Simo Bobda [13], Kouega and Sokeng Piewo [14], Ombouda [15], Sokeng Piewo [16]. Their findings revealed that the official bilingualism policy fails to produce bilingual Cameroonians; at all stages of language acquisition, this policy is found to be a sheer waste of resources. At the primary level of education, pupils are expected to be provided with "English that they will use... in their daily life requirements" (MINEDUC [1] p. 30). Unfortunately, most of the teachers have not been taught English let alone being taught how to teach English (Abang [3]). As a result, when primary school leavers move on the secondary education, they are re-taught the basics of English as they had learnt nothing worth building on. At the secondary school level, very little English is learnt for seven years. Examining the overall performance in English of secondary school leavers in a nation-wide survey, Sokeng Piewo [16] found that their level was irritatingly low. The situation at the tertiary level is no better, as many students desert lectures delivered in English. In all other domains (mass media, civil service etc.), English and its speakers are marginalised. Many instances have been reported of civil servants not attending to English-speaking customers on grounds that je ne comprends pas votre anglais là (I do not understand that English of yours.). This situation was predicted by Constable [5], who noted that "in Cameroon bilingual institutions... it would be completely impossible to function without French, whereas a poor knowledge of English would not constitute a handicap".

In October 2016, Government finally understood that its official French-English bilingualism policy had been a failure when lawyers in the two Anglophone regions of the country, i.e. the Northwest and the Southwest regions, took to the streets to 
complain about the high number of "officially monolingual" French-speaking lawyers who were posted to Anglophone Cameroon, making French the language used in court proceedings involving Anglophone citizens in Anglophone Cameroon and in the write-up of judicial and administrative documents. That was the last blow that let loose what has been referred to as the "Anglophone problem in Cameroon" (Konings and Nyamnjoh [17], Nkwi and Nyamnjoh [18], BAPEC [19], Kouega [20]). Similarly, in November 2016, Anglophone teachers launched a strike action partly to protest against an overflow into Anglophone schools of officially monolingual francophone teachers who know very little English and therefore teach Anglophone pupils in French or Pidgin. As can be seen, what triggered off the Anglophone problem in Cameroon is the failure of the francophone education sub-system to turn out a large number of bilingual citizens. Instead of admitting this failure and seeking possible solutions, Government rather deployed its heavily armed soldiers, who committed all sorts of human rights violations. Horrible and degrading images uploaded on the internet were made to circulate round the globe and, in reaction. Government ordered the complete shutdown of the internet in the two Anglophone regions. This last blow irked the Anglophone community in the country and abroad, to the point that a sizeable proportion of their members are now contemplating, if not outright secession, at least the return to federalism as it was in 1961.

As a possible way forward, Government unilaterally created a 15-member National Commission for the Promotion of Bilingualism and Multiculturalism. Strangely enough, none of these 15 members had done any work on bilingualism or multiculturalism prior to his/her appointment by presidential decree. This is another indication that, like the previous measures taken by Government, this last measure may not be able to contribute to the promotion of bilingualism in the country.

The present study focuses on the possible benefits earmarked for the few successful French-English bilinguals in the country and checks their evaluation of this official policy.

\section{Research Design}

This section considers the informants of the study, the setting, the instruments used, the material collected, the method of data collection and the method of data analysis. The informants were Cameroonians who could express themselves in French and English. They were to meet a number of requirements to be selected. First they were to be contacted at their place of work by the research assistants and were to indicate that they were French-English bilinguals; this excluded officially monolingual workers as well as non-working people. Second, they were to indicate their second official language which, in the Cameroonian context, is English for Francophones and French for Anglophones. Third, they were to claim that they could speak their second official language and finally, they were to claim that they were capable of effectively doing their daily work in French only and English only. Having identified the second official language of a 
potential informant, the research assistants, who were competent bilinguals, were to check this potential informant's competence in his claimed second official language by interacting with him in that language. When this test was conclusive, this informant was served a 16-item questionnaire written in that language i.e. French for Anglophones and English for Francophones. The focus of the questionnaire, which is reproduced in Appendix, was on the following issues: how the informants acquired bilingual competence, what they have benefited as a result of their being bilingual, and whether they believed Government was serious about its bilingualism policy.

A total of 450 copies of the questionnaire were made and 408 were returned, giving a return rate of $90.6 \%$. Information on the sex, age, educational level and linguistic repertoire of the respondents were not sought for a number of reasons. First, in Cameroon, female and male bilinguals especially civil servants, have the same treatment in terms of remuneration and promotion. Second, old bilinguals, especially civil servants, have no advantage over junior ones, apart from the fact that older workers of a given grade earn a higher salary than junior ones. Third, the educational level of a civil servant in Cameroon can be worked out from his occupation; for example, a journalist is someone who has spent at least three years of training in a tertiary level school of journalism and a medical doctor is someone who has spent seven years in a tertiary level medical school. Lastly, the linguistic repertoire of the respondents was overlooked. In Cameroon, successive governments have been reluctant to count Anglophones and Francophones. An attempt to count them, even in a piece of research work, may be misinterpreted by not only government officials but also the respondents themselves. Even though information on sex, age and other demographics were not sought, 9.4\% of 450 informants were suspicious: some of them found the questionnaire highly political and were therefore unwilling to fill it, while others considered it a bait used to push them into a trap. These 408 returns were subjected to a simple statistical analysis.

\section{Data Analysis}

The analysis is divided into four sub-sections labelled in turn: the process of acquisition of bilingual competence, the assistance received during the acquisition of bilingual competence, the benefits of individual French-English bilingualism, and finally, bilingualism in Cameroon: fallacy or fantasy? These are considered in turn.

\subsection{Process of Acquisition of Bilingual Competence}

The preliminary items of the questionnaire asked the informants to indicate whether they regarded themselves as French-English bilingual Cameroonians (Q1), how they had acquired bilingual competence (Q3), what their occupation was (Q2), and whether they could do their main job effectively using only French and only English (Q4). Of the many people contacted, 408 claimed that they were French-English bilinguals. The vast majority of them had acquired the 
second official language in the school setting, notably in universities and language centres like the Pilot Linguistic Centre and the B\&K Institute in Yaoundé. Some monolinguals studied in English-speaking countries and ended up becoming bilinguals. A few respondents mentioned in passing that the Church context helped to keep their bilingualism going; in fact, in many Pentecostal churches, messages passed on in French are usually repeated in English and vice versa. A few other informants, mainly Anglophones, reported that they learnt French through personal effort, usually by interacting with Francophones in their places of work and the neighbourhood. Regarding occupation, the bulk of these informants were civil servants i.e. teachers, translators, accountants, soldiers, office clerks, journalists etc. Others were employed in private businesses in such areas as journalism, law, cinema, hotel management, religion etc. All of these informants claimed that they could do their daily work in French only and in English only.

\subsection{Assistance Received during the Acquisition of Bilingual Competence}

Q5 asked these informants whether they received any form of assistance from Government simply because they were undergoing training in French-English bilingualism and the following result was obtained:

As the result shows, $75.49 \%$ of 408 informants reported that they did not receive any assistance from Government during their training (Table 1). Those who claimed to have been assisted were former students of the University of Yaoundé who used to be sent to Britain for a 6 - 12 month immersion programme. Unfortunately, this programme was discontinued a long time ago. Today, students specialising in French-English bilingualism do no longer go on internship. However, the University of Yaounde I (Yaounde is a francophone town) and the University of Buea (Buea is an Anglophone town) have set up an exchange programme, with their students changing towns for a duration of one term in the course of their training.

\subsection{Benefits of Individual French-English Bilingualism}

Asked whether their status of bilingual Cameroonians helped them to get their present jobs (Q6), the vast majority of informants replied "No", as shown in Table 2. A look at the occupations of those who said "Yes" (10.05\% of 408 informants) showed that they were translators working in both the public and private sectors. Actually, the only job reserved for bilinguals in the country is translation. All other jobs or positions can be occupied by monolinguals. Q7 inquired

Table 1. Assistance for training.

\begin{tabular}{lcc}
\hline $\begin{array}{l}\text { Q5. Did you receive any form of assistance from Government simply because you were } \\
\text { undergoing training in French-English bilingualism? }\end{array}$ \\
\hline Yes & No & Total \\
\hline $100(24.51 \%)$ & $308(75.49 \%)$ & 408 \\
\hline
\end{tabular}


Table 2. Recruitment of bilinguals.

\begin{tabular}{cccccc}
\hline \multicolumn{2}{l}{$\begin{array}{l}\text { Q6. Do you think that your status of a bilingual } \\
\text { Cameroonian helped you to get your present job? }\end{array}$} & \multicolumn{4}{c}{ Q7. Do you know of a officially monolingual } \\
\multicolumn{2}{c}{ Cameroonian who does the same job as you? }
\end{tabular}

whether these informants knew of officially monolingual Cameroonians who did the same jobs as them and the vast majority (96.08\%) said "Yes" including translators (Table 2). This means that in Cameroon, bilingual competence is not a requirement for job recruitment, as there are no jobs reserved for officially bilingual workers. Even in the domain of translation, some translators commented, it is not uncommon to find a service run by an officially monolingual head, which is an aberration.

Q8 asked the informants to indicate whether they had ever benefited from a scholarship/training thanks to the fact they were bilinguals. Unexpectedly, $97.06 \%$ gave a negative reply. The positive replies came from the domain of diplomacy in the public sector where a few clerks were posted to an English-speaking country because they were officially bilingual and the domains of hotel management (receptionists) and religion (Pentecostal pastors) in the private sector. Asked whether they had ever been appointed to higher posts thanks the fact they were officially bilingual (Q9), most informants (95.1\% of 408) said "No", as shown in Table 3. The few who said "Yes" came from the private sector, notably clerks in embassies and NGOs.

Workers are normally promoted at regular intervals throughout their working life. One form of promotion in Cameroon is change of grade and another is change of incremental position. Q10 asked the informants whether they had ever benefited from a change of grade thanks to the fact that they were bilinguals and the answer was "No". It was the same negative reply for Q11 inquiring about incremental positions (Table 4).

Thanks to missions, workers in Cameroon get extra benefits. These benefits help them to save part of their salaries. The more missions one has, the more money one saves, which is why all workers look forward to being sent on a mission. Q12 asked the informants whether they had gone on a mission thanks to the fact that they were bilinguals and most of them (97.79\% of 408 informants) answered "No" or with a hopeful tone, "Not yet". Q13 focused on distinctions awarded workers who have excelled or distinguished themselves in a positive way in bilingual matters. Informants were asked whether they had ever received such a distinction and the reply was almost unanimously "No". A few informants did say "Yes" (2.45\% of 408), with one of them sarcastically adding that he/she received "a handshake from the school principal as the best bilingual teacher in the school" (Table 5).

Informants were asked to mention any fringe benefits reserved for bilinguals they can think of. Specifically, Q14 asked them whether they had ever got anything in Cameroon thanks to the fact that they were bilinguals and the answer 
Table 3. In-service training and appointments of bilinguals.

\begin{tabular}{|c|c|c|c|c|c|}
\hline \multicolumn{3}{|c|}{$\begin{array}{l}\text { Q8. Since you have been working, have you } \\
\text { benefited from a scholarship/training thanks } \\
\text { to the fact that you were a bilingual? }\end{array}$} & \multicolumn{3}{|c|}{$\begin{array}{l}\text { Q9. Since you have been working, have you } \\
\text { been appointed to a higher post thanks to } \\
\text { the fact that you were a bilingual? }\end{array}$} \\
\hline YES & NO & Total & YES & NO & Total \\
\hline $12(2.94 \%)$ & 396 (97.06\%) & 408 & 388 (95.1\%) & $20(4.9 \%)$ & 408 \\
\hline
\end{tabular}

Table 4. Promotion of bilinguals.

\begin{tabular}{lcccc}
$\begin{array}{l}\text { Q10. Since you have been working, have you } \\
\text { benefited from a change of grade thanks to the } \\
\text { fact that you were a bilingual? }\end{array}$ & $\begin{array}{l}\text { Q11. Since you have been working, have you } \\
\text { benefited from an incremental position thanks } \\
\text { to the fact that you were a bilingual? }\end{array}$ \\
\hline NES & Total & YES & NO & Total \\
\hline- & $408(100 \%)$ & $112.7 \%$ & $397(97.3 \%)$ & 408 \\
\hline
\end{tabular}

Table 5. Missions and work distinctions awarded to bilinguals.

\begin{tabular}{|c|c|c|c|c|c|}
\hline \multicolumn{3}{|c|}{$\begin{array}{l}\text { Q12. Since you have been working, have you } \\
\text { gone on a mission thanks to the fact that you } \\
\text { were a bilingual? }\end{array}$} & \multicolumn{3}{|c|}{$\begin{array}{l}\text { Q13. Since you have been working, have you } \\
\text { received any distinction (a medal or anything } \\
\text { thanks to the fact that you were a bilingual? }\end{array}$} \\
\hline YES & NO & Total & YES & NO & Total \\
\hline $9(2.21 \%)$ & 399 (97.79\%) & 408 & $10(2.45 \%)$ & $398(97.55 \%)$ & 408 \\
\hline
\end{tabular}

was a resounding "No". However, a few informants (3.68\% of 408 informants) said they had got something and one cited an allowance worth CFA Francs 200,000 (i.e. $\approx £ 200$ ) he got from Brasseries du Cameroun (a brewery company) for his good performance in both the French and English subjects at the GCE A' Level. Q15 further asked whether there was anything that bilinguals of a given level had and that monolinguals of that same level did not have and the answer once again was "No", as presented in Table 6.

However, these informants rather listed the various advantages that bilinguals can potentially have in any context including Cameroon. Below are reproduced the most common ones cited:

- bilinguals have many opportunities for jobs and they can interact with a variety of people if they happen to find themselves in a francophone or Anglophone country;

- they are open to the world, but monolinguals are not;

- politicians can easily win favours when they can express themselves in two languages;

- bilingual secretaries are said to have a greater advantage when looking for a job.

These potential advantages that a bilingual may have over a monolingual, it should be noted, are mere wishful potentials not facts.

As this sub-section has shown, these informants reported that they had received no benefits in Cameroon thanks to the fact that they were French-English bilinguals. Incidentally, they reported that they had no specific benefits that monolinguals did not have. 
Table 6. Encouragements for bilinguals.

\begin{tabular}{|c|c|c|c|c|c|c|}
\hline \multicolumn{3}{|c|}{$\begin{array}{l}\text { Q14. Have you ever got anything in Cameroon } \\
\text { thanks to the fact you were a bilingual? }\end{array}$} & \multicolumn{4}{|c|}{$\begin{array}{l}\text { Q15. Consider the Cameroonian society as a } \\
\text { whole: is there anything that bilinguals of a } \\
\text { given level have and that monolinguals } \\
\text { of that same level do not have? }\end{array}$} \\
\hline YES & NO & Total & YES & NO & Blanks & Total \\
\hline $15(3.68 \%)$ & $393(96.32 \%)$ & 408 & $7(1.72 \%)$ & $351(86.03 \%)$ & $50(12.25 \%)$ & 408 \\
\hline
\end{tabular}

\subsection{Bilingualism in Cameroon: Fallacy or Fantasy?}

Q16 asked the informants to indicate whether they felt that Government was serious about its policy of French-English bilingualism and the answers in Table 7 were given (Table 7).

The informants who said "Yes" (3.92\% of 408) mentioned the various measures that Government had taken over the years, which are listed in Section 1 above. They believed that these measures were good but, as the researchers cited above have shown, these measures did not increase the number of bilinguals in the country. The bulk of the informants $(96.08 \%)$ said "No" and cited a series of possible effective measures which Government ought to have taken. The three most frequent measures proposed include, in order: salary increase, appointments to higher posts and finally a requirement for an appointment to high level Government posts.

\section{Discussion}

As the analysis above has shown, the informants of this study rejected the various measures taken so far to boost individual bilingualism in the country. Huge resources have been spent on bilingualism for very limited results. The failure is so serious that it is reported that in international contexts, francophone Cameroonians tend to be less proficient in English than their counterparts from other francophone countries like Chad and Senegal. There is a need to take the bull by the horns. Government should consider the problem of return on investment very seriously. Acquiring a second official language is investment, human investment which is not without costs. Workers spend a considerable amount of their time and money to become bilingual and this sacrifice is made in anticipation of future benefits that may come in the form of higher payoff and promotion in the workplace. When their sacrifice does not yield any benefits, it is but obvious that they will remain monolingual as is the case with the vast majority of Cameroonian workers. There is therefore a need to set up a reward scheme for bilingual workers in Cameroon.

A potential scheme is the certification of bilingual competence and the valorisation of this certificate. The basic certificate that a francophone child obtains is the Certificat d'Etudes Primaires (CEP) with its Anglophone equivalent being the First School Leaving Certificate (FSLC). To uphold peaceful coexistence and national integration, Government can decide that bilingual competence is henceforth compulsory, with the primary school exit certificate in each citizen's 
Table 7. Seriousness of the official bilingualism policy.

Q16. Consider the Cameroonian society as a whole: do you think that Government is serious about its policy of French-English bilingualism? If yes, cite one major effective measure it has taken. If no, cite one effective measure it ought to have taken.

\begin{tabular}{ccc}
\hline Yes & No & Total \\
\hline $16(3.92 \%)$ & $392(96.08 \%)$ & 408 \\
\hline
\end{tabular}

second official language being the minimum grade. To put in simple terms all francophone Government workers would be required to include a copy of the First School Leaving Certificate (FSLC) in their files for recruitment, promotion or change of grades. Similarly, Anglophone workers will have to provide the Certificat d'Etudes Primaires (CEP). Candidates without this certificate will be recruited, promoted or posted to other localities only when there are no other candidates of equal competence. If these measures were applied, then officially monolingual francophone lawyers and teachers would not have found themselves in Anglophone courts and schools. When this certification proposal is implemented, Government will save much money which is wasted today in unproductive Pilot Linguistic Centres. The money thus saved could be used to subsidise other major language-related issues such as the design of courses for the teaching of Cameroon indigenous languages and the purchase of schoolbooks.

\section{Conclusion}

This paper examined the possible benefits of French-English bilingual competence to the individual working citizen in Cameroon, using the survey method. A total of 408 French-English bilingual workers took part in the exercise and a number of interesting findings were obtained. Government has over the years taken a number of measures to promote bilingualism but all these measures failed to turn out a high number of bilinguals in the country for a number of reasons. First, no form of encouragement is provided for active learners who exert themselves to acquire the second official language. Second, no specific benefits are envisaged for workers who have toiled for many years and can in the end effectively operate in the two official languages of the country. Consequently both officially monolingual and bilingual workers have the same treatment in the labour market. This situation has led the informants to conclude that Government is not serious about its policy of French-English bilingualism. This lack of seriousness has pushed a great proportion of Anglophone citizens to start contemplating, at best, federalism and, at worst, outright secession from francophone Cameroon. A scheme of certification of bilingual competence needs to be put in place to curb avoidable social unrest.

\section{References}

[1] MINEDUC (2001) Ministère de l'Education Nationale [Ministry of Education] Programmes Officiels de l'Enseignement Primaire (Niveaux I, II et III). [Official Syllabi for Primary Education (Levels I, II and III)]. Imprimerie Saint John, 
Yaounde.

[2] Kouega, J.P. (2003) English in Francophone Elementary Grades in Cameroon. Language and Education: An International Journal, 17, 408-420.

https://doi.org/10.1080/09500780308666860

[3] Abang, R. (2007) The Spoken English of Francophone Elementary School Teachers: A Case Study of Ecole Publique de Kondengui. Unpublished Maitrise Dissertation, University of Yaoundé I.

[4] MINEDUC (2000) Ministère de l'Education Nationale [Ministry of Education] Final Report on the Reinforcement of Bilingualism in the Cameroon Education System. A Manuscript.

[5] Constable, D. (1977) Bilingualism in the United Republic of Cameroon. English Language Teaching Journal, 29, 249-253. https://doi.org/10.1093/elt/XXXI.3.249

[6] Tchoungui, G. (1983) Focus on Official Bilingualism in Cameroon: Its Relationship to Education. In Koenig, E.L., Chia, E. and Povey, J., Eds., A Sociolinguistic Profile of Urban Centers in Cameroon, Cross Road Press, Los Angeles, 93-116.

[7] Kouega, J.P. (1999) Forty Years of Official Bilingualism in Cameroon. English Today, 15, 38-43. https://doi.org/10.1017/S0266078400011251

[8] Kouega, J.P. (2005) Promoting French-English Individual Bilingualism through Education in Cameroon. Journal of Third World studies, 22, 185-196.

[9] Kouega, J.P. (2007) The Language Situation in Cameroon. Current Issues in Language Planning (CILP), 8, 1-94. https://doi.org/10.2167/cilp110.0 http://www.findarticles.com/p/articles/mi_qa3821/is_200504/ai_n13642809

[10] Kouega, J.P. (2008) Bilingualism at Tertiary Level Education in Cameroon: The Case of the University of Yaounde II (Soa). ISB6: Proceedings of the 6th International Symposium on Bilingualism (30 May-2 June, 2007, University of Hamburg). http://archiv.gwin.gwiss.uni-hamburg.de/isb6/proceedings/kouega.pdf

[11] Biloa, E. (1999) Bilingual Education at the University of Yaounde I: The Teaching of French to English-speaking Students. In: Echu, G. and Grundstorm, A.W., Eds., Official Bilingualism and Linguistic Communication in Cameroon, Peter Lang, New York, 53-74.

[12] Echu, G. (1999) Le Bilinguisme Officiel au Cameroun: Critique et Perspectives. In: Echu, G. and Grundstorm, A.W., Eds., Official Bilingualism and Linguistic Communication in Cameroon, Peter Lang, New York, 189-201.

[13] Simo Bobda, A. (2004) Tendances des Recherches sur le Bilinguisme (Francais-Anglais) au Cameroun. Revue Internationale des Arts, Lettres et Sciences Sociales-RIALSS, 39-57.

[14] Kouega, J.P. and Sokeng Piewo, S.C. (2013) Performance of Francophone Secondary School Leavers in English Structure and Written Expression. English Linguistics Research, 2, 86-106.

[15] Ombouda Onana, E. (2008) The Oral Performance of Ewondo Learners of English: A Case Study Conducted in Lycée de Mefono. Unpublished Maitrise dissertation, University of Yaoundé I.

[16] Sokeng Piewo, S.C. (2011) The English Language Proficiency of Francophone Secondary School Leavers in Cameroon. Unpublished PhD Thesis, University of Yaounde I.

[17] Konings, P. and Nyamnjoh (1997) The Anglophone Problem in Cameroon. Journal of Modern African Studies, 35, 207-229. https://doi.org/10.1017/S0022278X97002401 
[18] Nkwi, P.N. and Nyamnjoh, F.B. (Eds.) (1997) Regionalism and National Integration in Cameroon: Lessons Learned and the Uncertain Future. ASC/ICASSRT, Yaounde.

[19] BAPEC (Bamenda Provincial Episcopal Conference) (2017). Memorandum to President Paul Biya on the Current Situation in the Northwest and Southwest Regions.

http://www.cameroon-info.net/article/cameroon-bamenda-provincial-episcopal-confe rence-memorandum-to-president-paul-biya-on-the-current-situation-in-278001.html

[20] Kouega, J.P. (2017) The Anglophone Problem in Cameroon: Focus on education. The Voice, No. 53, 6-7. 


\section{Appendix}

\section{Questionnaire}

I am a postgraduate student in the Faculty of Letters, University of Yaoundé I. I am interested in examining the benefits of French-English official bilingualism to Cameroonian workers. Could you help me by answering the questions below! As my findings are totally dependent on your answers, I will be grateful if you could be as accurate as possible.

1. Do you regard yourself as a French-English bilingual Cameroonian?

2. What is your occupation?

3. How did you acquire bilingual competence?

4. Can you do your main job effectively using only French and only English?

5. Did you receive any form of assistance from Government simply because you were undergoing training in French-English bilingualism?

6. Do you think that your status of a bilingual Cameroonian helped you to get your present job? Do insert comments if you have any.

7. Do you know of a monolingual Cameroonian who does the same job as you? Do insert comments if you have any.

8. Since you have been working, have you benefited from a scholarship/training thanks to the fact that you were a bilingual? Do insert comments if you have any.

9. Since you have been working, have you been appointed to a higher post thanks to the fact that you were a bilingual? Do insert comments if you have any.

10. Since you have been working, have you benefited from a change of grade thanks to the fact that you were a bilingual? Do insert comments if you have any. 
11. Since you have been working, have you benefited from an incremental position (changement d'échelon) thanks to the fact that you were a bilingual? Do insert comments if you have any.

12. Since you have been working, have you gone on a mission thanks to the fact that you were a bilingual? Do insert comments if you have any.

13. Since you have been working, have you received any distinction (a medal or anything thanks to the fact that you were a bilingual? Do insert comments if you have any.

14. Have you ever got anything in Cameroon thanks to the fact you were a bilingual? Do insert comments if you have any.

15. Consider the Cameroonian society as a whole: is there anything that bilinguals of a given level have and that monolinguals of that same level do not have? Do insert comments if you have any.

16. Consider the Cameroonian society as a whole: do you think that Government is serious about its policy of French-English bilingualism? If yes, cite one major effective measure it has taken. If no, cite one effective measure it ought to have taken. 